\title{
Full-Scale Well Instrumented Large Diameter Bored Pile Load Test in Multi Layered Soil: A Case Study of Damietta Port New Grain Silos Project $^{1}$
}

\author{
M. Eid \#, A. Hefny^, T. Sorour\#, Y. Zaghloul ${ }^{\$}$ and M. Ezzat ${ }^{\$ *}$ \\ \#Ain Shams University, Department of Civil Engineering, Cairo, Egypt \\ ${ }^{\wedge}$ United Arab Emirates University, Department of Civil \& Environmental Engineering, UAE \\ \$Higher Institute of Engineering, Department of Civil Engineering, Shorouk City, Cairo, Egypt \\ Received 25 Nov 2017, Accepted 26 Jan 2018, Available online 10 Feb 2018, Vol.8, No.1 (Jan/Feb 2018)
}

\begin{abstract}
A Large diameter bored pile with diameter of $1.00 \mathrm{~m}$ and length of $34.00 \mathrm{~m}$ has been implemented in multi layered soil. The pile was tested under three axially loading and unloading cycles, in order to determine the load settlement curve and assess the ultimate pile capacity. Extensive investigation was carried out to obtain reliable soil properties at the examined pile location, through in situ and laboratory soil tests. Twelve strain gauges were fixed on pile steel reinforcement bars at top of each soil layer level. Moreover, four dial gauges were set up at pile head. Also, three telltales were extended to three different levels inside the pile. The pile load test field measurements are presented in the form of load settlement and load distribution curves for different loading steps. In addition, the pile ultimate capacity is calculated using different codes criterions and compared with the loading test results.
\end{abstract}

Keywords: Large diameter bored pile, Settlement, Pile load distribution, Pile installation, Instrumentation, Full scale pile load test, Pile behavior.

\section{Introduction}

Major number of factors influences the ultimate capacity of large diameter bored piles. These factors include method of boring, method of concreting, quality of concrete, construction staff expertise, the ground conditions and the pile geometry. It is recommended, through different international geotechnical and foundation design standards, to use in situ loading test to assess the pile capacity of large diameter bored piles (ECP 202/4 (2005), DIN 4014 (1990) and ASHTOO LRFD (2005), although field pile load tests are very expensive and time-consuming.

A very good opportunity is allowed to perform loading test on well instrumented pile in one of Egyptian mega projects (Figure1), Damietta Port new grain silos. This project is one of Damietta Port development requirements. It was decided to establish metallic silos (cone Type) with storage capacities of 70,000 tons, consisting of 10 storage cells, each of them with diameter of $25 \mathrm{~m}$. Because of the large loads acting on these silos due to their high capacities, large diameter pile foundations are recommended. Two non-

*Corresponding author M. Ezzat is Assistant Lecturer, Geotechnical Eng., Department of Civil Engineering, Higher Institute of Engineering, Shorouk city, Cairo, Egypt; ORCID ID: 0000-0001-77519773; DOI: https://doi.org/10.14741/ijcet.v8i01.10895 working piles were tested under a maximum load of $300 \%$ of its working load, in order to determine accurate pile ultimate capacity.

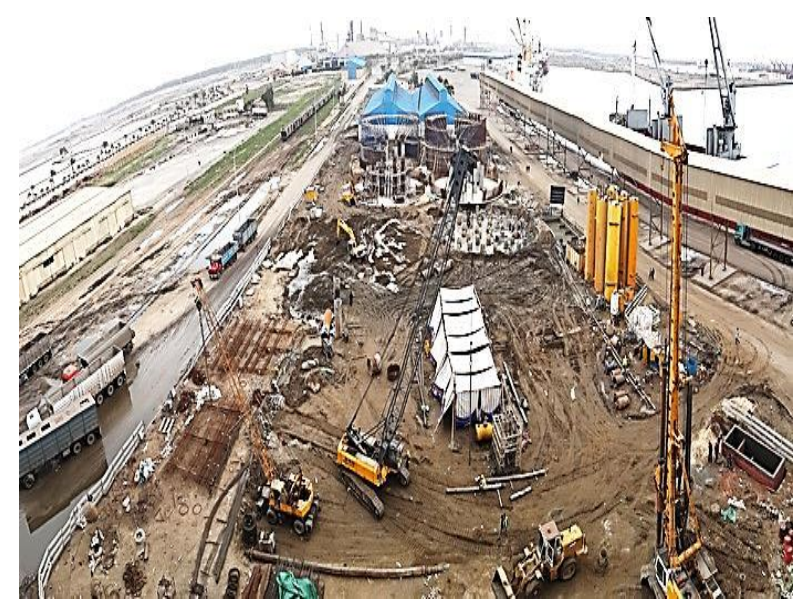

Fig.1 Damietta Port New Grain Silos site.

The Egyptian code of practice (ECP202/4), recommends to obtain large diameter bored pile ultimate capacity using in situ pile loading test results.

A safety factor of (1.75-2.00) should be considered to determine the pile allowable (Design) load. In case of impossibility to perform pile loading test at the 
design phase, Egyptian code suggests considering that full mobilization of pile skin friction occur at a settlement of $1 \%$ of the shaft diameter. Also, ECP202/4 suggests that pile base resistance mobilization occur at $15 \mathrm{~cm}$ settlement for piles resting on sandy soil. Using these proposed settlement values, designer can determine pile design load due to proposed values of unit skin friction and soil bearing stress.

It was necessary to perform extensive site investigation and soil testing in order to determine reliable soil parameters, which are essential for pile design load calculations.

\section{Site Investigations}

According to Egyptian code of practice (ECP202/2 (2005)), twelve boreholes were carried out with a depth of $45 \mathrm{~m}$ each at silos locations as indicated in Figure 2.

The twelve boreholes were performed using mechanical rotary drilling techniques. Samples were extracted every $1 \mathrm{~m}$ along each borehole depth. Figure 3 shows soil lithology for boreholes number 2, 3, 6, 7, 10 and 11 at Section (A-A) location (Figure 2). The soil lithological section illustrates that soil layers are consistent at the mentioned boreholes locations.

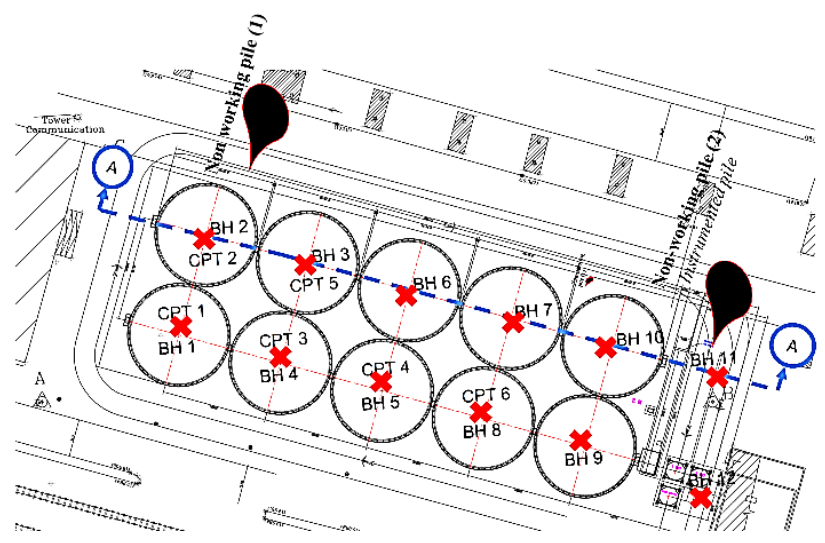

Fig.2 Soil boreholes and non- working piles' locations at silos site layout.

It was decided to carry out two field loading tests on non-working piles. The locations of these two piles (1 and 2) are shown in Figure 2. One of them (Pile No. 2) was fully instrumented to study the behavior of the large diameter bored pile under loading. It can be seen from Figure 2 that the non-working instrumented pile (pile No. 2) is located near borehole number eleven (BH 11), therefore the soil profile at $\mathrm{BH} 11$ was taken as representative to that at the instrumented pile location.

\subsection{Soil Profile at Borehole No. (11)}

Figure 4, shows the primary classification of soil layers at location of $\mathrm{BH} 11$. The ground water existed at a depth of $1.30 \mathrm{~m}$ below the ground surface. Description of the encountered soil layers and their properties are discussed in the next sections.

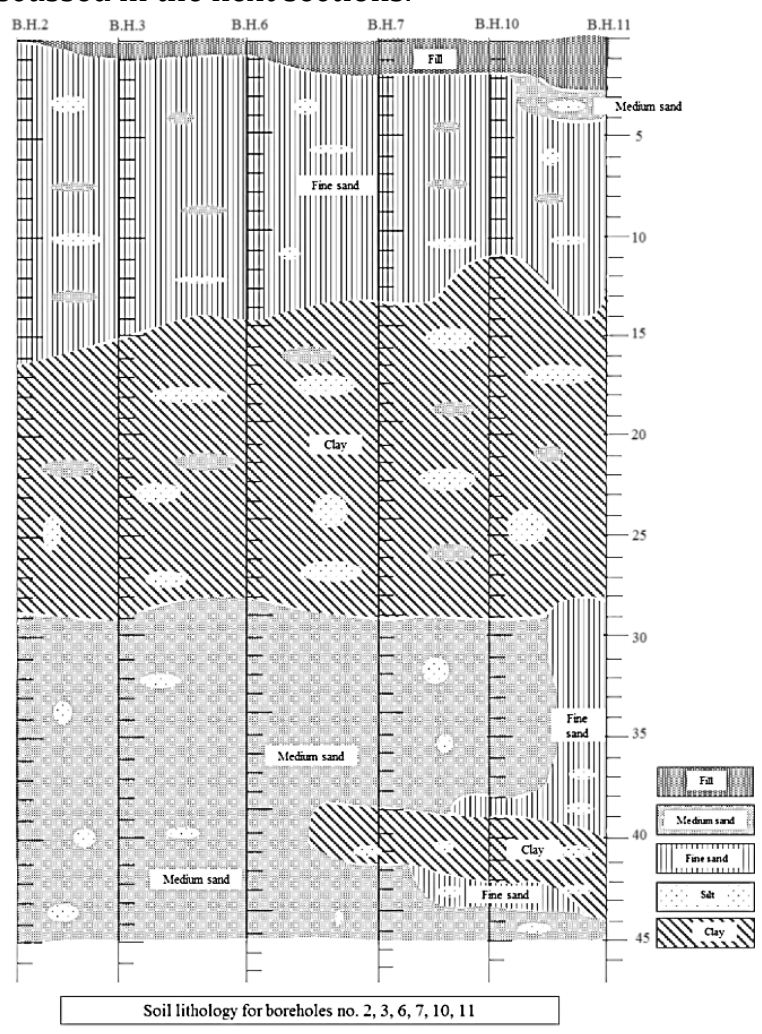

Fig.3 Soil lithology for boreholes number 2, 3, 6, 7, 10 and 11 (section A-A)

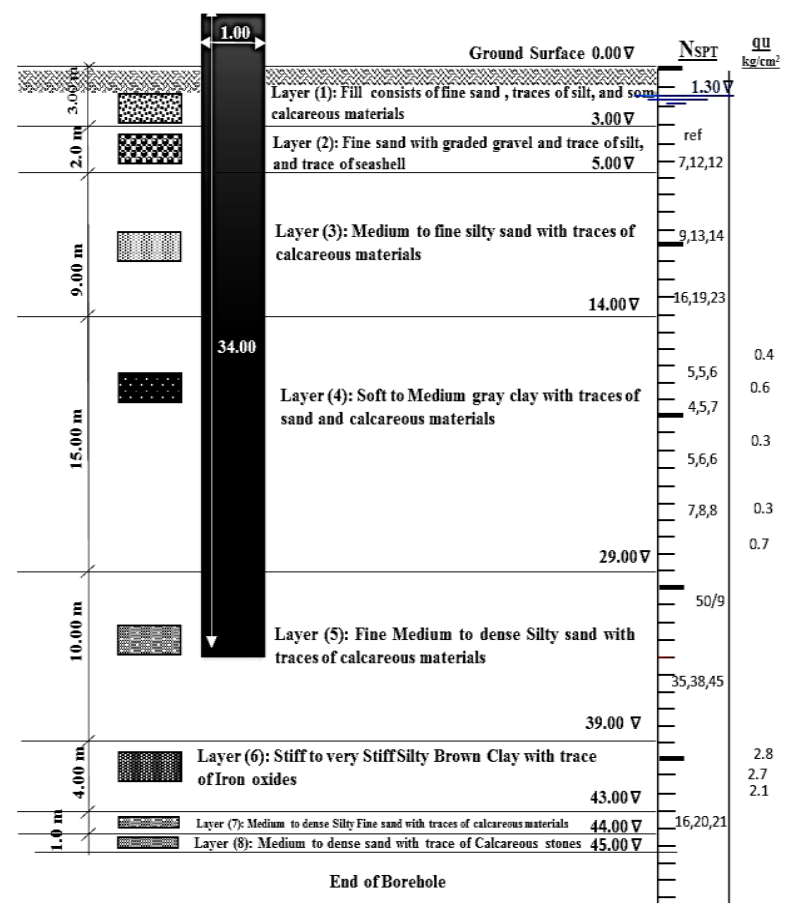

Fig.4 Soil Profile at location of BH 11

\subsection{Engineering Properties of Soil Layers}

Extensive laboratory and in situ soil tests were carried out to determine the properties of the soils at BH 11. 


\subsubsection{Laboratory tests}

\subsubsection{Sieve analysis test results}

In order to classify soil layers, sieve analysis test has been carried out for each 1-meter depth samples. According to the visual inspection and the sieve analysis test results shown in Table 1 , soil layers at location of $\mathrm{BH} 11$ were primarily classified into eight soil layers. Layer (1) starts at level (0.00) to level $(-3.00)$ which is fill layer consisting of fine sand, traces of silt, and some calcareous materials. Layer (2) starts from level $(-3.00)$ to level $(-5.00)$, and consists of fine sand with graded gravel and traces of silt and seashell. Layer (3) starts from level $(-5.00)$ to level $(-14.00)$, and consists of medium to fine silty sand with traces of calcareous materials. Layer (4) starts from level ($14.00)$ to level (-29.00), and consists of soft to medium clay with trace of calcareous materials and fine sand. Layer (5) starts from level (-29.00) to (-39.00) and consists of fine medium to dense silty sand with trace of calcareous materials. Layer (6) starts from level $(-39.00)$ to level $(-43.00)$, and consists of stiff to very stiff brown Clay with trace of iron oxides. Layer (7) starts from level $(-43.00)$ to level $(-44.00)$ and consists of medium to dense silty fine sand with traces of calcareous materials. Layer (8) starts from level (44.00), and extends till the end of the borehole, and consists of medium to dense sand with traces of calcareous materials.

Table 1 Sieve analysis test results

\begin{tabular}{|c|c|c|c|c|c|c|c|}
\hline layer & Sample level & $S_{200}(\%)$ & $\mathrm{D}_{10(\mathrm{~mm})}$ & $\mathbf{D}_{30(\mathrm{~mm})}$ & $D_{60}(\mathrm{~mm})$ & $\mathbf{C}_{\mathbf{U}}$ & $\mathbf{C}_{\mathbf{c}}$ \\
\hline 1 & -2.00 & $6 \%$ & 0.085 & 0.17 & 0.22 & 2.6 & 1.5 \\
\hline 2 & -5.00 & $19 \%$ & - & 0.09 & 0.17 & - & - \\
\hline 3 & $\begin{array}{l}-10.00 \\
-13.00 \\
\end{array}$ & $\begin{array}{l}23 \% \\
22 \% \\
\end{array}$ & - & $\begin{array}{l}0.09 \\
0.09 \\
\end{array}$ & $\begin{array}{l}0.19 \\
0.19 \\
\end{array}$ & - & - \\
\hline 4 & $\begin{array}{l}-16.00 \\
-24.00 \\
-28.00 \\
\end{array}$ & $\begin{array}{l}95 \% \\
98 \% \\
99 \% \\
\end{array}$ & $\begin{array}{l}- \\
- \\
-\end{array}$ & $\begin{array}{l}- \\
- \\
-\end{array}$ & $\begin{array}{l}- \\
- \\
- \\
\end{array}$ & $\begin{array}{l}- \\
- \\
-\end{array}$ & $\begin{array}{l}- \\
- \\
-\end{array}$ \\
\hline 5 & $\begin{array}{l}-31.00 \\
-34.00 \\
-35.00 \\
-38.00\end{array}$ & $\begin{array}{c}2 \% \\
1 \% \\
20 \% \\
23 \% \\
\end{array}$ & $\begin{array}{c}0.13 \\
0.14 \\
- \\
- \\
\end{array}$ & $\begin{array}{l}0.25 \\
0.23 \\
0.10 \\
0.09 \\
\end{array}$ & $\begin{array}{l}0.32 \\
0.32 \\
0.19 \\
0.19 \\
\end{array}$ & $\begin{array}{c}2.5 \\
2.3 \\
- \\
- \\
\end{array}$ & $\begin{array}{c}1.5 \\
1.2 \\
- \\
-\end{array}$ \\
\hline 6 & -43.00 & $100 \%$ & - & - & - & - & - \\
\hline 7 & -45.00 & $19 \%$ & - & 0.13 & 0.38 & - & - \\
\hline
\end{tabular}

Where,

$S_{200:}$ percentage of fine material that passing from sieve number 200. (\%)

$\mathrm{D}_{10}$ : the diameter in the particle-size distribution curve corresponding to $10 \%$ by weight passing, also referred to the effective size $(\mathrm{mm})$

$\mathrm{D}_{30}$ : grain size, indicated by the gradation curve at the $30 \%$ passing level (mm).

$\mathrm{D}_{60}$ : diameter corresponding to $60 \%$ by weight passing, indicated by the gradation curve at the $60 \%$ passing level (mm). $\mathrm{C}_{\mathrm{U}}$ : uniformity coefficient $\left(\mathrm{D}_{60} / \mathrm{D}_{10}\right)[-]$

Cc: Curvature coefficient of the gradation curve $\left(\mathrm{D}^{2} 30 / \mathrm{D}_{60} * \mathrm{D}_{10}\right)[-]$.

Based on sieve analysis test results, soil layers' coefficient of permeability $\left(\mathrm{K}_{\text {per }}\right)$ was calculated for sand soil layers using the following equation (Hazen (1892)).

$\mathrm{K}_{\text {per }}=\mathrm{C}\left(\mathrm{D}_{10}\right)^{2}$

Where,

$\mathrm{K}_{\text {per: }}$ coefficient of permeability $(\mathrm{cm} / \mathrm{sec})$

C: constant, typically assumed to be 100 .

$\mathrm{D}_{10}$ : grain size corresponding to $10 \%$ by weight passing, also referred to as the effective size ( $\mathrm{mm})$.

\subsubsection{Water content and Atterberg limits}

Undisturbed clay samples were extracted at depths of $18.0 \mathrm{~m}, 20.0 \mathrm{~m}, 25.0 \mathrm{~m}, 28.0 \mathrm{~m}$, and $41.0 \mathrm{~m}$ below ground surface. These samples were tested to obtain the
Atterberg limits and the natural water content to classify the cohesive soil and to determine the relative consistency $\left(\mathrm{I}_{\mathrm{c}}\right)$ using the following equation (ECP (202/2)).

$\mathrm{I}_{\mathrm{C}}=\frac{\mathrm{L} \cdot \mathrm{L}-\mathrm{w} \cdot \mathrm{C}}{\mathrm{Ip}}$

Where,

L.L: soil liquid limit (\%)

W.C: soil water content $(\%)$

$\mathrm{I}_{\mathrm{p}}$ : plasticity index.

Based on the determined values of relative consistency $\left(I_{C}\right)$, clay samples were classified, and the undrained cohesion $\left(\mathrm{C}_{\mathrm{u}}\right)$ for each clay sample was estimated and given in Table 2. 
Table 2 Natural water content and Atterberg limits test results

\begin{tabular}{|c|c|c|c|c|c|c|}
\hline Sample level (m) & W.C \% & L.L \% & P.L \% & $\mathbf{I}_{\mathbf{c}}$ & Clay Classification & Cu (kN $\left.\backslash \mathbf{m}^{\mathbf{2}}\right)$ \\
\hline-18.0 & 67.06 & & & & & \\
\hline-20.0 & 63.22 & 83.22 & 41.64 & 0.43 & Soft Clay & $12.5-25$ \\
\hline-25.0 & 64.69 & & & & & $12.5-25$ \\
\hline-28.0 & 58.09 & 81.66 & 40.19 & 0.52 & Soft Clay & $50-100$ \\
\hline-41.0 & 38.28 & 61.12 & 31.37 & 0.76 & Stiff Clay & \\
\hline
\end{tabular}

Where,

$\mathrm{I}_{\mathrm{c}}$ : relative consistency for clay samples.

$\mathrm{C}_{\mathrm{u}}$ clay soil undrained cohesion $\left(\mathrm{kN} \backslash \mathrm{m}^{2}\right)$.

\subsubsection{Consolidation Test (Oedometer Test)}

Consolidation test was carried out on clay soil samples extracted from site at depth of $-20 \mathrm{~m}$ below ground surface. Based on test results, soil volume compressibility coefficient $\left(\mathrm{m}_{\mathrm{v}}\right)$ was determined with value of $2.89 * 10^{-4} \mathrm{~m}^{2} / \mathrm{kN}$. Consequently, clay soil constrained modulus $\left(E_{s}\right)$ was estimated to be 3450 $\mathrm{kN} \backslash \mathrm{m}^{2}$ using the following equation.

$$
\mathrm{E}_{\mathrm{s}}=1 / \mathrm{m}_{\mathrm{v}}
$$

\subsubsection{Pocket Penetrometer (PP)}

The pocket penetrometer is a hand held calibrated penetration device and is commonly used to obtain an approximate value of clayey soils unconfined strength Table 3 presents predicted values of $\left(\mathrm{q}_{\mathrm{u}}\right)$ for clay samples at variable depths using the pocket penetrometer.

Table 3 Pocket penetrometer in-situ test results

\begin{tabular}{|c|c|c|c|c|}
\hline \multirow{2}{*}{ Sample } & \multirow{2}{*}{ Extraction depth (m) } & Undrained shear strength(qu $\mathbf{u}$ & Undrained cohesion (Cu) & Clay Classification \\
\cline { 3 - 5 } & & $\mathbf{k N} \backslash \mathbf{m}^{\mathbf{2}}$ & $\mathbf{k N} \backslash \mathbf{m}^{\mathbf{2}}$ & \\
\hline $\mathbf{1}$ & 16 & 40.0 & 20.0 & Soft clay \\
\hline $\mathbf{2}$ & 18 & 60.0 & 30.0 & Medium clay \\
\hline $\mathbf{3}$ & 21 & 30.0 & 15.0 & Soft clay \\
\hline $\mathbf{4}$ & 27 & 70.0 & 35.0 & Medium clay \\
\hline $\mathbf{5}$ & 41 & 280.0 & 140.0 & Very Stiff clay \\
\hline $\mathbf{6}$ & 43 & 270.0 & 135.0 & Very Stiff clay \\
\hline $\mathbf{7}$ & 45 & 210.0 & 105.0 & Very Stiff clay \\
\hline
\end{tabular}

\subsubsection{In-Situ Field Tests and Soil Properties}

\subsection{2.a Standard penetration test (SPT)}

Standard penetration test was performed using a hammer of $0.62 \mathrm{kN}$ weight dropped from $76.0 \mathrm{~cm}$ height and the number of blows required to penetrate the soil $30 \mathrm{~cm}\left(\mathrm{~N}_{30}\right)$ is recorded at variable depths. The measured values are given in Figure 4.
The required corrections due to overburden effect, underground water table and the borehole diameter effect, were performed according to the Egyptian code of practice (202/1 (2005)). The corrected values are given in Table 4. Using these values ( $\mathrm{N}_{\text {Corr. }}$ ), sandy soils friction angle and undrained cohesion values of clayey soils were determined and calculated values are listed in Table 4.

Table 4 Obtained soil parameters using SPT corrected values

\begin{tabular}{|c|c|c|c|c|c|}
\hline Layer & $\mathbf{N}_{30}$ & $\mathbf{N}_{\text {corr. }}$ & $\begin{array}{c}\text { Friction angle } \\
(\phi)\left({ }^{\circ}\right)\end{array}$ & $\begin{array}{c}\text { Undrained shear } \\
\text { strength }\left(q_{u}\right) k N \backslash m^{2}\end{array}$ & Classification \\
\hline 1 & - & - & - & - & - \\
\hline 2 & 24 & 25.5 & $32^{\circ}-36^{\circ}$ & - & Medium dense sand \\
\hline 3 & $\begin{array}{l}27 \\
42\end{array}$ & 26 & $32^{\circ}-36^{\circ}$ & - & Medium dense sand \\
\hline 4 & $\begin{array}{l}11 \\
12 \\
12 \\
16 \\
\end{array}$ & $\begin{array}{l}6 \\
8 \\
\end{array}$ & - & $\begin{array}{r}50 \\
100 \\
\end{array}$ & Medium to stiff clay \\
\hline 5 & 83 & 28.25 & $32^{\circ}-36^{\circ}$ & - & Medium dense sand \\
\hline 6 & - & - & - & - & - \\
\hline 7 & 41 & 17.75 & $32^{\circ}-36^{\circ}$ & - & Medium dense sand \\
\hline 8 & $>50$ & 20 & $36^{\circ}-40^{\circ}$ & - & Dense sand \\
\hline
\end{tabular}


Young's modulus $\left(E_{s}\right)$ for sand soil layers, are estimated using the SPT original N-values according to the following recommended correlations by the ECP (202/3 (2005)).

For silty sand soil,

$\mathrm{E}_{\mathrm{s}}=4 \mathrm{~N}\left(\mathrm{~kg} / \mathrm{cm}^{2}\right)$

For medium to fine sand soil,

$\mathrm{E}_{\mathrm{s}}=7 \mathrm{~N}\left(\mathrm{~kg} / \mathrm{cm}^{2}\right)$

For dense sand soil,

$\mathrm{E}_{\mathrm{s}}=10 \mathrm{~N}\left(\mathrm{~kg} / \mathrm{cm}^{2}\right)$

\subsection{2.b Static cone penetration test (CPT)}

Six static cone penetration tests (CPT) were carried out at project site, at locations shown in Figure 2. Test steps followed ECP202/1 and ASTM D3441 (2004) procedures. Cone tip resistance $\left(\mathrm{q}_{\mathrm{c}}\right)$ and the sleeve friction resistance $\left(f_{s}\right)$ were measured, and the obtained values along $30 \mathrm{~m}$ depth below the ground surface are shown in Figure 5.

Robertson's (1990) soil classification criterion shown in Figure 6, was used to classify soil layers based on CPT test results. The obtained soil classification from CPT number six is shown in Figure 7. It can be seen that there is agreement between the soil classification obtained from the CPT test results and that obtained from visual inspections and laboratory tests.

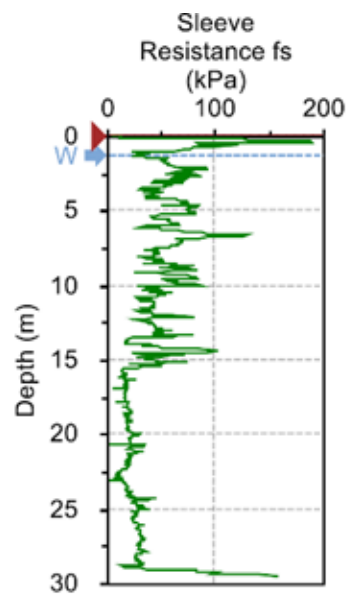

(b)

Fig.5 Cone penetration test in-situ measurements (according to CPT test no.6)

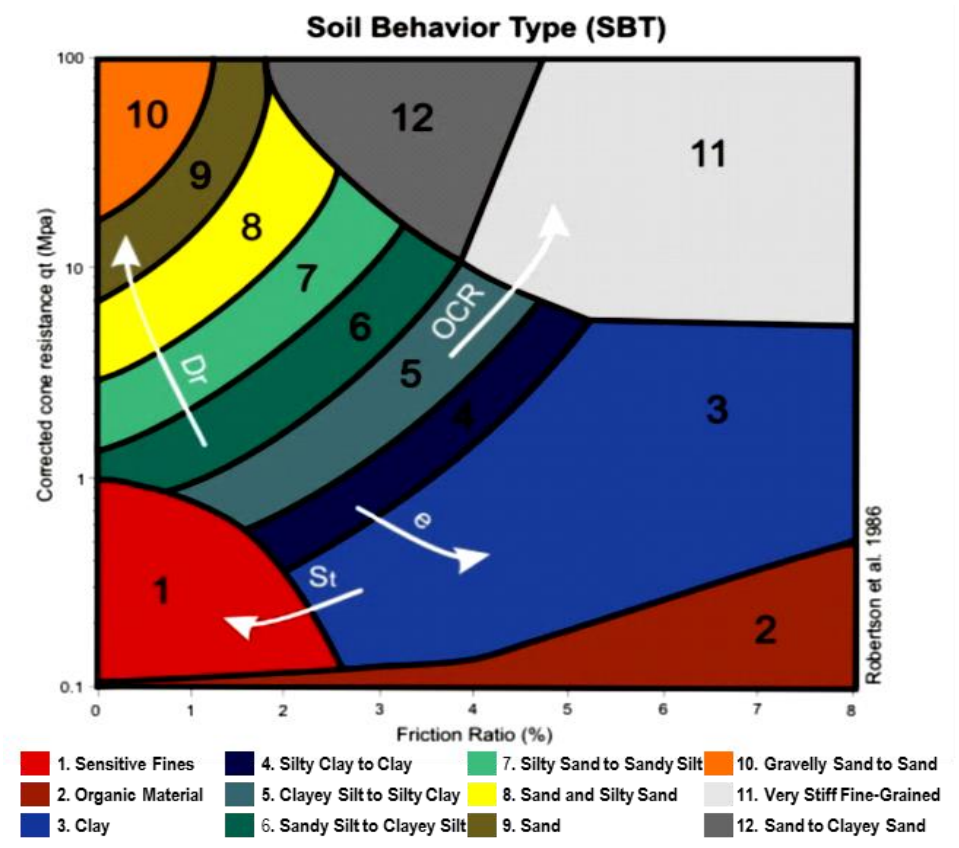

Fig.6 Soil classification using CPT tip resistance values $\left(\mathrm{q}_{\mathrm{c}}\right)$, after Robertson (1990) 
Table 5 Engineering properties of the soil layers

\begin{tabular}{|c|c|c|c|c|c|c|c|c|c|c|c|c|c|}
\hline$\stackrel{\circ}{\rightleftarrows}$ & 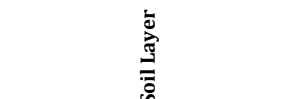 & 竞 & 党 & 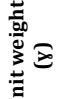 & \multicolumn{3}{|c|}{$\begin{array}{l}\text { Young modulus } \\
\text { (Es) }\end{array}$} & \multicolumn{4}{|c|}{ Undrained Cohesion (Cu) } & \multicolumn{2}{|c|}{$\begin{array}{c}\text { Friction angle } \\
(\phi)\end{array}$} \\
\hline & $\vec{\Xi}$ & छ & छ & $\sum_{z}^{n}$ & \multicolumn{3}{|c|}{$\mathbf{k N} / \mathbf{m}^{2}$} & \multicolumn{4}{|c|}{$\mathbf{k N} / \mathbf{m}^{2}$} & \multicolumn{2}{|c|}{$\left[{ }^{\circ}\right]$} \\
\hline & & & & & के & : & 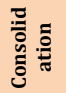 & 寅 & ثิ & 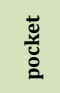 & 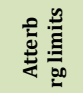 & के & 荌 \\
\hline 1 & $\begin{array}{l}\text { Fill consists of fine sand, traces } \\
\text { of silt, and some calcareous } \\
\text { materials }\end{array}$ & $0-3$ & 3.0 & 16.5 & 25000 & 28000 & - & - & - & - & - & - & 27 \\
\hline 2 & $\begin{array}{l}\text { Fine sand with graded gravel } \\
\text { and trace of silt, and trace of } \\
\text { seashell }\end{array}$ & 3-5 & 2.0 & 16.5 & 30000 & 55000 & - & - & - & - & - & $32-36$ & 35 \\
\hline 3 & $\begin{array}{l}\text { Medium to fine silty sand with } \\
\text { traces of calcareous materials }\end{array}$ & $\frac{5-10}{10-14}$ & 9.0 & 16.5 & 35000 & 85000 & - & - & - & - & - & 32 & $\frac{30}{35}$ \\
\hline 4 & $\begin{array}{l}\text { Soft to Medium gray clay with } \\
\text { traces of sand and calcareous } \\
\text { materials }\end{array}$ & $\frac{14-22}{22-29}$ & 15.0 & 16.4 & - & 5700 & 3450 & $\begin{array}{l}25 \\
50\end{array}$ & $\begin{array}{l}19.0 \\
33.2\end{array}$ & $15-35$ & $12.5-25$ & - & - \\
\hline 5 & $\begin{array}{l}\text { Fine Medium to dense Silty sand } \\
\text { with traces of calcareous } \\
\text { materials }\end{array}$ & 29-39 & 10.0 & 17.9 & 58000 & 120000 & - & - & - & - & - & $32-36$ & 34 \\
\hline 6 & $\begin{array}{l}\text { Stiff to very Stiff Silty Brown } \\
\text { Clay with trace of Iron oxides }\end{array}$ & $39-43$ & 4.0 & 18.5 & 20000 & - & - & 100 & - & $\begin{array}{l}105- \\
140\end{array}$ & 100 & - & - \\
\hline 7 & $\begin{array}{l}\text { Medium to dense Silty Fine sand } \\
\text { with traces of calcareous } \\
\text { materials }\end{array}$ & $43-44$ & 1.0 & 17.9 & 35000 & - & - & - & - & - & - & $32-36$ & - \\
\hline 8 & $\begin{array}{l}\text { Medium to dense sand with } \\
\text { trace of Calcareous stones }\end{array}$ & $44-45$ & 1.0 & 18.0 & 50000 & - & - & - & - & - & - & $36-40$ & - \\
\hline
\end{tabular}

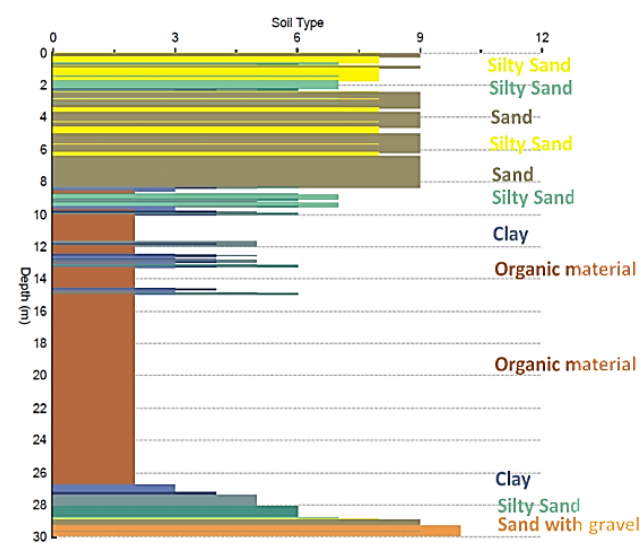

Fig.7 Soil type classification based on CPT test results.

Moreover, tip resistance values $\left(\mathrm{q}_{\mathrm{c}}\right)$ have been used to determine undrained cohesion $\left(\mathrm{C}_{\mathrm{u}}\right)$ values for clay soils in accordance with (ECP202/1) Equation 5. As demonstrated in Table 5 , the undrained strength values calculated from CPT results are in good agreement with those obtained from SPT results.

-For cohesive soil:

$\mathrm{C}_{\mathrm{u}}=\left(q_{c}-\sigma_{v}\right) / N_{k}$

Where,

$\sigma_{v}$ : soil overburden pressure at cone tip level $\left(\mathrm{kN} \backslash \mathrm{m}^{2}\right)$. $\mathrm{N}_{\mathrm{k}}$ : correction factor considered equal (15) for normally consolidated clay.

According to Robertson and Campanella (1983), friction angle ( $\left.\varnothing^{\prime}\right)$ for sand soils using CPT measurements were determined. Also, using measurements of CPT test, unit weight of each soil layer was estimated according to Robertson and Cabal (2010), and the calculated values are shown in Table 5.

Friction angle obtained values are compared with their corresponding values that obtained from SPT test. It was found that, friction angles determined using CPT test results are higher than the values obtained from SPT test. This is due to the Robertson and Campanella method is valid for clean sand. As presented before sieve analysis test results showed that some of sand soil layers contains fine silty components with different percentages. Bowles (1997) suggested an approximate Eq. (6) to determine silty sand soil friction angle $\left(\varnothing^{\prime}\right)$ using tip resistance values $\mathrm{q}_{\mathrm{c}}(\mathrm{MPa})$. The calculated friction angles using Equation (6) are given in Table (5).

-For silty sand soil:

$\emptyset=29^{\circ}+\sqrt{q_{c}}-5^{\circ}$

Using field CPT test results. Soil Young's modulus (E) for sand soils are obtained using Bellotti et al. (1989) method due to the effective overburden stresses value at each sand layer level. In addition, Young's modulus for clay soils were obtained using Duncan \& Buchignani (1987) equation (7). The calculated Young's modulus using CPT measurement are given in Table 5 for the eight soil layers.

$\mathrm{Es}=\mathrm{K}^{*} \mathrm{~S}_{\mathrm{u}}$

Where 
$\mathrm{S}_{\mathrm{u}}$ : undrained shear strength $\left(\mathrm{kN} \backslash \mathrm{m}^{2}\right)$.

$\mathrm{K}$ : the constant of proportionality, which is a function of stress history (OCR) and soil plasticity index (determined using Duncan chart to be 300 ).

It was noted that, soil Young's modulus values obtained using CPT test measurement are greater than those obtained using SPT test measurements. This may be attributed to the assumptions considered by ECP $202 / 3$ in development of the empirical equations for calculation of soil Young's modulus from SPT N-values in order to suit the nature of the Egyptian soils.

\section{Large Diameter Bored Pile Design Load}

The Egyptian code of practice (ECP202/4) recommends to determine the ultimate load capacity of large diameter piles from pile loading test at the design stage. In case of impossibility to perform a pile load test, the code suggests to use an empirical method to predict the pile capacity. In this method, pile unit skin friction for each soil layer is estimated from values of SPT and then the pile side capacity is calculated based on pile dimensions and it is considered to be fully mobilized at a settlement value of $1 \%$ of the pile diameter. The pile base resistance is then assumed to be fully mobilized at a pile settlement of $15 \mathrm{~cm}$ for granular soils or $10 \%$ of the pile diameter. The Egyptian code provides a correlation between the value of the base bearing pressure at failure and the failure settlement from which the base resistance can be calculated. A bilinear relation between total load and settlement can then be constructed and the total capacity is considered to occur at a settlement value of $10 \%$ of the pile diameter. This prediction method is used to determine the ultimate capacity of the pile as follows.

According to soil profile at BH 11, layer (3) from level $-5.0 \mathrm{~m}$ to $-14.0 \mathrm{~m}$, and layer (5) from $-29.0 \mathrm{~m}$ to $39.0 \mathrm{~m}$, are sandy layers that are suitable to be the pile bearing layer. Accordingly, during the design stage, pile length is assumed to be either $13.0 \mathrm{~m}$ or $34.0 \mathrm{~m}$. While the pile diameter is assumed to be $1.0 \mathrm{~m}$.

Figure 8 shows the predicted pile load settlement results according to ECP202/4 estimations, for pile with different lengths of 34.0 and $13.0 \mathrm{~m}$. It can be seen from Figure 8 that the pile with $34.0 \mathrm{~m}$ length achieved $4028.6 \mathrm{kN}$ friction resistance and $1779 \mathrm{kN}$ bearing resistance, with a total pile ultimate load of $5807.6 \mathrm{kN}$. The pile with length of $13.0 \mathrm{~m}$ achieved $2166.6 \mathrm{kN}$ friction load, while the bearing load has the same value of ( $1779 \mathrm{kN})$ with a total ultimate load of $3945.6 \mathrm{kN}$.

On the other hand, for piles of length of $13 \mathrm{~m}$, the calculated pile group settlement for the silo's raft with pile spacing of $2.5 \mathrm{D}$ was larger than the allowable settlement $(120 \mathrm{~mm})$ due to the large settlement of the clay layer underlying the pile's bearing sand layer.

Finally, because of the large loads acting on these silos due to its high capacities and in order to optimize the number of required piles. It was decided to use the large diameter bored piles with length of $34.0 \mathrm{~m}$ and calculated ultimate load of about $6000 \mathrm{kN}$. The allowable pile capacity is estimated to be $3000 \mathrm{kN}$ by considering a factor of safety of 2.0 .

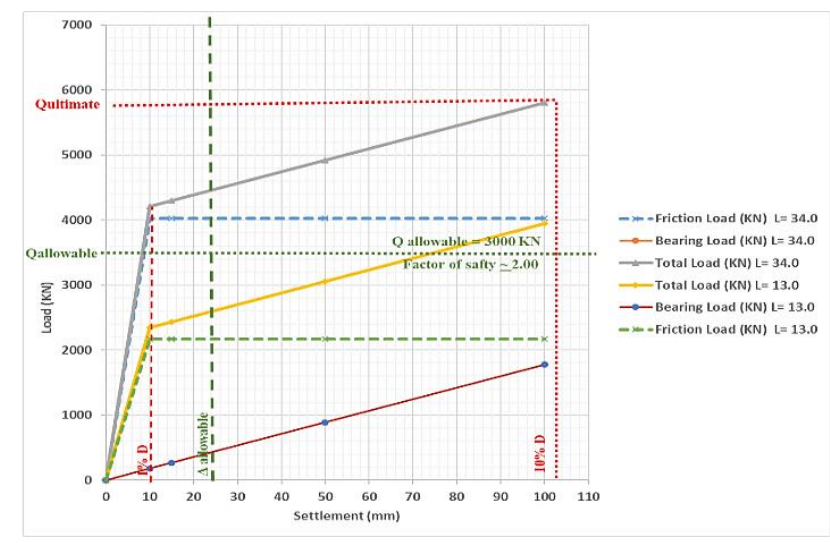

Fig.8 Pile design load calculations according to ECP 202/4 for different pile lengths of 13.0 and $34.0 \mathrm{~m}$

\section{Pile Instrumentation, Installation and Testing}

This section provides the method of large diameter bored pile instillation sequence, instrumentation erection technique and testing procedure.

\subsection{Bored pile installation}

Surveying tools were employed to locate the planned position of the bored pile, core cutter machine was used to cut a certain volume of shallow soil to provide the required volume for displacement of the short temporary steel casing that was with diameter slightly larger than the planned pile diameter's $(1.0 \mathrm{~m})$. Steel case was used to provide the required stability of the shallow soil layers during the boring, also to act as a guidance for the drilling tools, and guarantees verticality of boring. As shown in Figure 9, mechanical auger drilled soil inside the steel casing and additional section of steel casing was added with progress of drilling. The pile wall stability during drilling was also assured by the presence of a stable suspension of Bentonite slurry. The top surface of the bentonite was kept at distance not less than $1.0 \mathrm{~m}$ above the existing water table.

After reaching the designed depth of pile $(34.0 \mathrm{~m})$, the drilling tool was removed and water was pumped to clean the drilled borehole. Reinforcement cage was installed with welded segments according to pile shaft length. Pipe trim was used for concrete casting with enough length to protect concrete from segregation This pipe ended with inverted cone to provide steady rate of continuous concrete pumping. Finally, the steel temporary casing was removed at the end of concrete casting process. Concrete cubes samples were taken from pile casted concrete during pumping. The determined compressive strength of the concrete after 28 curing days, was $35 \mathrm{MN} / \mathrm{m}^{2}$. 


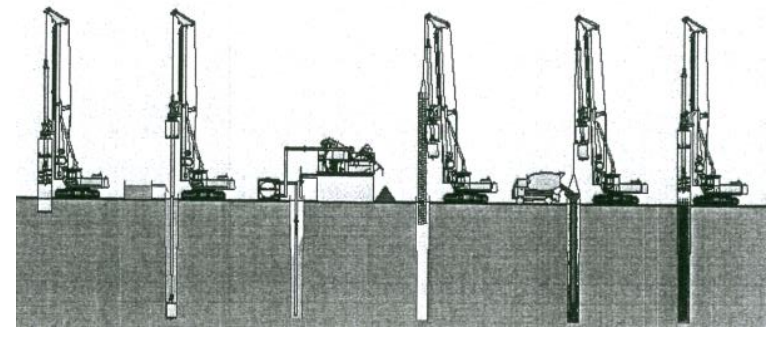

Fig.9 Sequence of drilling and concreting of piles.

\subsection{Pile instrumentation}

An instrumented pile load test often involves loading the pile up to an appropriately defined failure. In this test, pile shaft is supplied with dial gauges, and telltales with extensometers, so that the pile load settlement curves can be obtained. The vibrating wire strain gauges "Sister Bar" instrumentations are also used to allow the internal load in the tested pile shaft to be determined through their measured strains. Consequently, the distribution of the pile axial load with depth (vertical load-transfer along the pile shaft) can be determined for different applied load increments. Next sections provide the details of the used instrumentations in this test.

\subsubsection{Vibrating wire strain gauges}

According to Geokon instruction manual (1995), sister bars vibrating wire strain gauges are often chosen for cast in-place concrete piles, where concrete is casted into a drilled shaft, because they are more rugged and better able to maintain their alignment than embedment type strain gages.

The Model 4911 vibrating wire Rebar Strain Meter "Sister Bar" consists of a short length $(356 \mathrm{~mm})$ of high strength steel welded between two long sections of reinforcing bar. It is designed to be wire tied in parallel with the structural rebar. The small diameter of the bar minimizes its effect on the sectional modulus of the concrete. The cable exits from the strain meter through a small block of protective epoxy, as shown in Figure 10 .

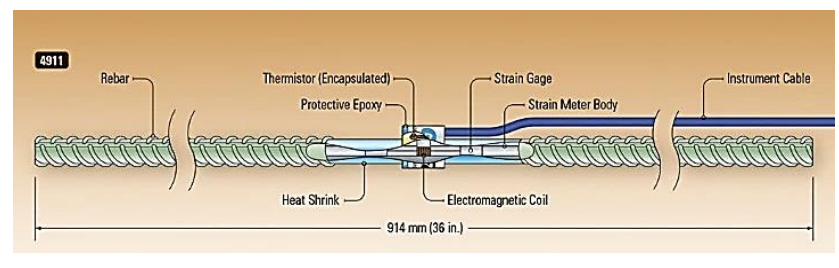

Fig.10 Model 4911 Rebar Strain Meter "Sister Bar"

Figure 11 presents twelve vibrating wire strain gauges erected on the reinforcing steel bars of the instrumented pile to measure strains at four different levels of the pile. Table 6 summarizes the quantities and locations of the strain gauges along the pile shaft.
Table 6 Distribution of strain gauges along pile shaft

\begin{tabular}{|c|c|c|}
\hline $\begin{array}{c}\text { Location of Strain } \\
\text { Gauges }\end{array}$ & $\begin{array}{c}\text { Level } \\
\text { (m) }\end{array}$ & $\begin{array}{c}\text { Number and ID of } \\
\text { strain gauges per } \\
\text { level }\end{array}$ \\
\hline $\begin{array}{c}\text { Near the pile head and top } \\
\text { of upper sand layer }\end{array}$ & $(-1.00)$ & $3(1,2 \mathrm{and} 3)$ \\
\hline $\begin{array}{c}\text { Interface between the } \\
\text { upper sand layer and the } \\
\text { soft clay layer }\end{array}$ & $(-14.00)$ & $3(4,5 \mathrm{and} 6)$ \\
\hline $\begin{array}{c}\text { Interface between the soft } \\
\text { clay layer and the lower } \\
\text { sand layer }\end{array}$ & $(-29.00)$ & $3(7,8 \mathrm{and} 9)$ \\
\hline Near the toe level & $(-33.00)$ & $3(10,11$ and 12$)$ \\
\hline
\end{tabular}

Strain gauges were calibrated and connected with readout device to collect and record steel bars strains during pile loading test. Each vibrating wire rebar strain meter was equipped with a thermistor for reading temperature. The thermistor gives a varying resistance output as the temperature changes.

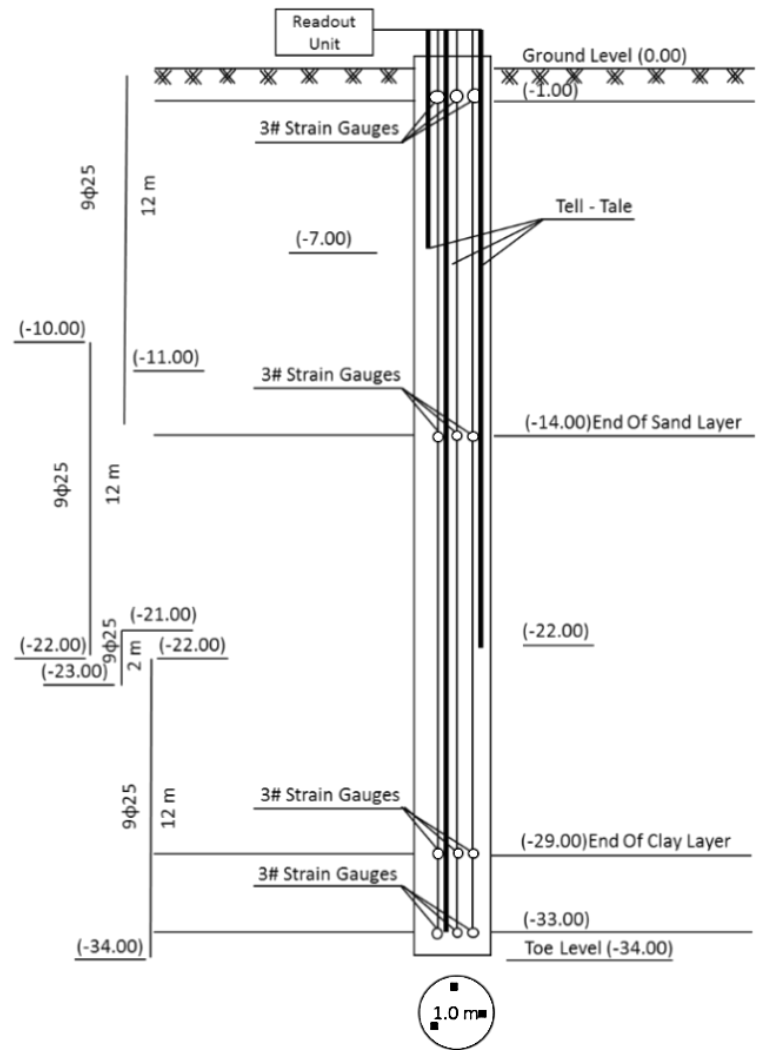

Fig.11 Exact locations of strain gauges and Tell-Tale distribution

\subsubsection{Extensometers (Tell-Tales)}

The Geokon Model A-9 of retrievable extensometer is used for the measurement of extensions and contractions along the concrete pile. It is particularly useful in concrete cast in place pile testing where it can be installed inside a PVC or steel pipe. The main advantage of the A-9 model (Figure 12 [a]) is its ability to be retrieved and use repeatedly, after monitoring completion, the pneumatic pressure is released from pressure manifold Figure 12[b] which retracts the 
anchor pistons and allows removal of the rod for further use. as shown in Figure 12[d]. Tell-Tale is a rod with its lower end connected to the concrete pile (usually at the toe) and free from the pile along its overall length by means of a PVC guide pipe arrangement. By attaching a dial gauge at the upper end of the rod and measuring the change of distance between the rod top and the pile head, the shortening of the pile during the test is monitored.

In this test, three Tell-Tales (Geokon Model A-9) have been used to measure the pile displacement at three different levels as indicated in Table 7 and Figure 11. Using these Tell-Tales, the displacement of the pile at the three mentioned levels is obtained, as the measured pile shortening subtracted from the movement of the pile head. Extensometer's rods were protected from concrete by PVC (51mm diameter) pipes, as illustrated in Fig 13. Readings are accomplished using GK-405 readouts device (Figure 12 [c]).

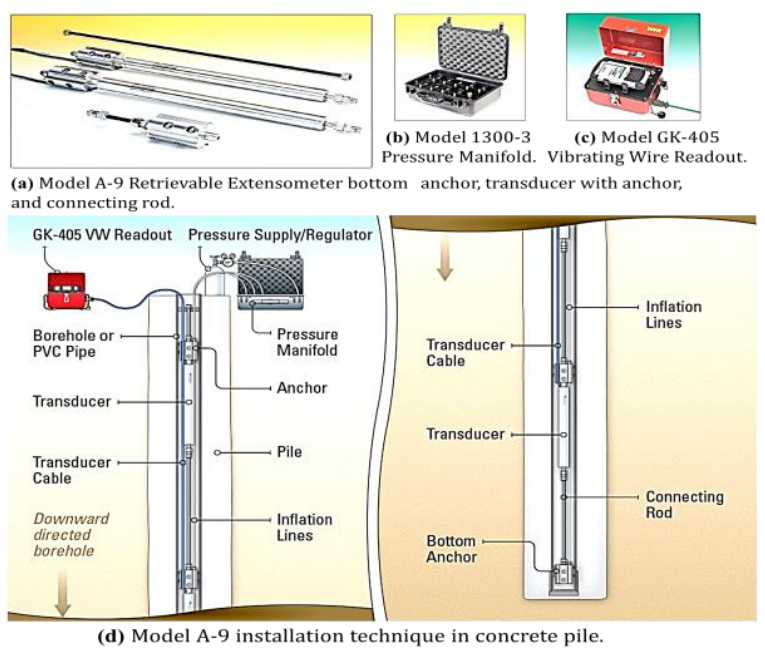

Fig. 12 Extensometers components and Operating Principle

Table 7 Distribution of Tell-Tales along the pile shaft

\begin{tabular}{|c|c|c|}
\hline $\begin{array}{c}\text { Location of Strain } \\
\text { Gauges }\end{array}$ & $\begin{array}{c}\text { Level } \\
\text { (m) }\end{array}$ & $\begin{array}{c}\text { Number of Tell-Tales } \\
\text { per Level }\end{array}$ \\
\hline $\begin{array}{c}\text { In the middle of the } \\
\text { upper sand layer }\end{array}$ & $(-7.00)$ & 1 \\
\hline $\begin{array}{c}\text { In the middle of the soft } \\
\text { clay layer }\end{array}$ & $(-22.00)$ & 1 \\
\hline Near the toe level & $(-33.00)$ & 1 \\
\hline
\end{tabular}

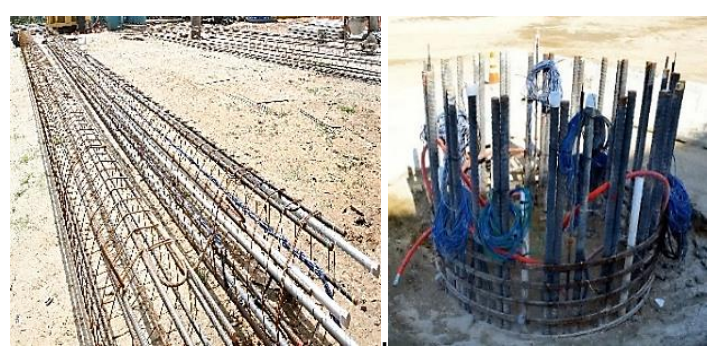

Fig.13 Extensometers devices and the rods before and after pile concrete casting
4.3 Loading test of the instrumented large diameter bored pile

Reaction system with a loading crown ring beam was provided and restrained by nine ground anchors group, which were uniformly distributed around the pile. Anchors were inclined with equal angles (ranging from $9^{0}$ to $12^{\circ}$ ) to the vertical axis. With these angles, it was assured that the distance between the pile and the center of gravity of grout body of any anchor was more than five times the pile diameter (5D) as required by the Egyptian code. (ECP 202/4).

Load was applied by two hydraulic jacks placed between the pile head and the anchored loading crown, the maximum capacity of each jack is about $6000 \mathrm{kN}$ The arrangements of the loading test are shown in Figure 14. Pile was tested under a maximum load of $9000 \mathrm{kN}$, which is three times the design load. The loading and unloading procedures followed in the pile test are given in Table 8. Also, pile settlement was measured using the four dial gauges at pile head level and using the three Tell-Tales at the mentioned levels in Table 7 . The strain gauges readings were also recorded for each loading step.

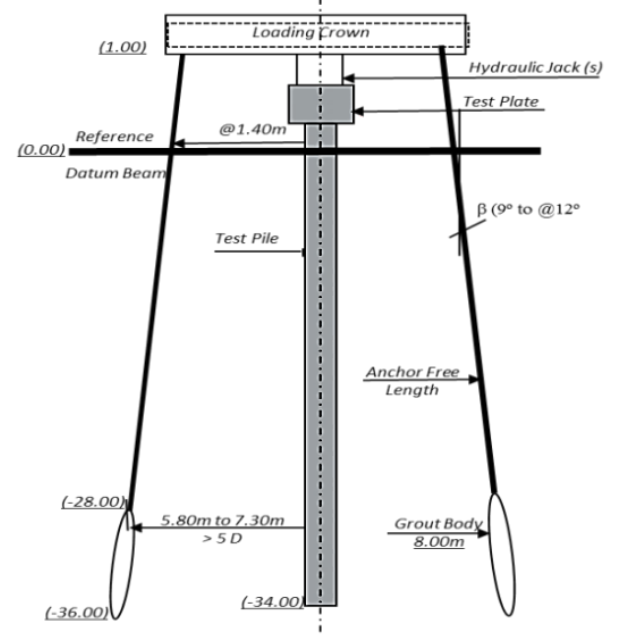

Fig.14 Reaction system and pile loading test arrangement

Table 8 Loading/unloading cycle's

\begin{tabular}{|c|c|}
\hline \multicolumn{2}{|c|}{ Cycle (1) } \\
\hline $\begin{array}{c}\text { Load } \\
{[\mathrm{kN}]}\end{array}$ & Time \\
\hline 0 & ---- \\
\hline 750 & $1 \mathrm{hr}$. \\
\hline 1500 & $1 \mathrm{hr}$. \\
\hline 2250 & $1 \mathrm{hr}$. \\
\hline 3000 & $12 \mathrm{hrs}$ \\
\hline 2250 & $15 \mathrm{~min}$ \\
\hline 1500 & $15 \mathrm{~min}$ \\
\hline 750 & $15 \mathrm{~min}$ \\
\hline 0.0 & $4 \mathrm{hrs}$. \\
\hline \multicolumn{2}{|c}{}
\end{tabular}

\begin{tabular}{|c|c|}
\hline \multicolumn{2}{|c|}{ Cycle (2) } \\
\hline $\begin{array}{c}\text { Load } \\
{[\mathrm{kN}]}\end{array}$ & time \\
\hline 3000 & $3 \mathrm{hrs}$ \\
\hline 3750 & $3 \mathrm{hrs}$ \\
\hline 4500 & $3 \mathrm{hrs}$ \\
\hline 5250 & $3 \mathrm{hrs}$ \\
\hline 6000 & $12 \mathrm{hrs}$ \\
\hline 5250 & $15 \mathrm{~min}$ \\
\hline 4500 & $15 \mathrm{~min}$ \\
\hline 3750 & $15 \mathrm{~min}$ \\
\hline 3000 & $15 \mathrm{~min}$ \\
\hline 2250 & $15 \mathrm{~min}$ \\
\hline 1500 & $15 \mathrm{~min}$ \\
\hline 750 & $15 \mathrm{~min}$ \\
\hline 0.0 & $4 \mathrm{hrs}$. \\
\hline
\end{tabular}

\begin{tabular}{|c|c|}
\hline \multicolumn{2}{|c|}{ Cycle (3) } \\
\hline $\begin{array}{c}\text { Load } \\
{[\mathrm{kN}]}\end{array}$ & Time \\
\hline 6000 & 3 hrs. \\
\hline 6750 & 3 hrs. \\
\hline 7500 & 3 hrs. \\
\hline 8250 & 3 hrs. \\
\hline 9000 & $12 \mathrm{hrs}$ \\
\hline 8250 & $15 \mathrm{mins}$ \\
\hline 7500 & $15 \mathrm{mins}$ \\
\hline 6750 & $15 \mathrm{mins}$ \\
\hline 6000 & $15 \mathrm{mins}$ \\
\hline 5250 & $15 \mathrm{mins}$ \\
\hline 4500 & $15 \mathrm{mins}$ \\
\hline 3750 & $15 \mathrm{mins}$ \\
\hline 3000 & $15 \mathrm{mins}$ \\
\hline 2250 & $15 \mathrm{mins}$ \\
\hline 1500 & $15 \mathrm{mins}$ \\
\hline 750 & $15 \mathrm{mins}$ \\
\hline 0.0 & 4 hrs. \\
\hline
\end{tabular}




\section{Test Results and Analysis}

\subsection{Measurements of pile settlement}

Figure 15 shows the pile settlement average values that was measured by the four dial gauges (precision of $0.01 \mathrm{~mm}$ ) at pile head level, under each loading and unloading increment.

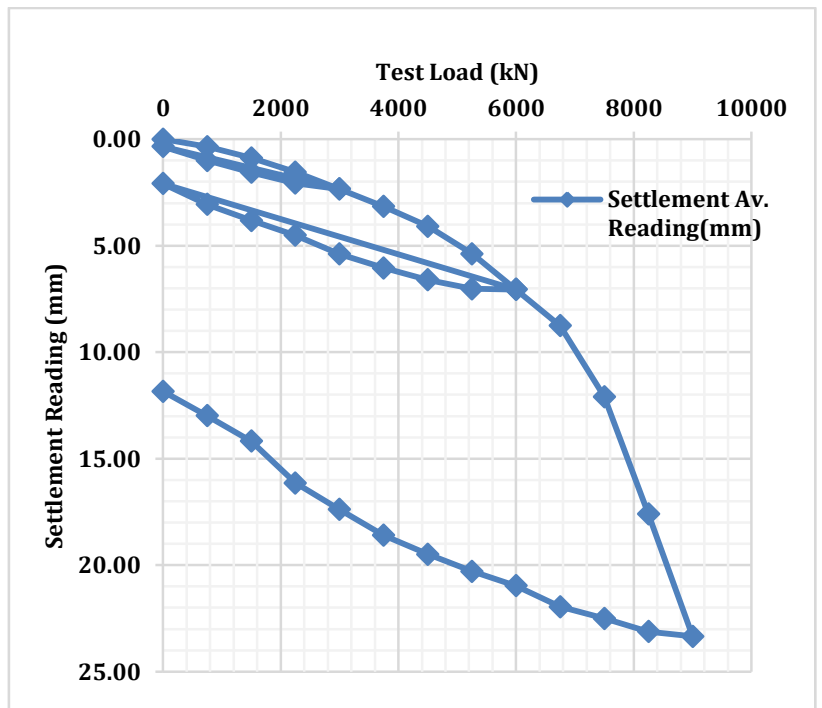

Fig.15 Pile settlement average measured values under three loading and unloading cycles.

It can be seen from Fig. 15 that pile settlement was about $4.0 \mathrm{~mm}$ at a load of $4500 \mathrm{kN}(150 \%$ of its working load), $7.0 \mathrm{~mm}$ under load of $6000 \mathrm{kN}(200 \%$ of its working load) and, about $23.50 \mathrm{~mm}$ under load of $9000 \mathrm{kN}$ (300\% of its working load). It can be noted that at $9000 \mathrm{kN}$ applied load the induced settlement is about $2.4 \%$ the pile diameter $(2.4 \% \mathrm{D})$, which is nearly equal to the allowable settlement under 1.5 times the allowable load (3000 kN).

The settlement at three different levels of $(-7.00) \mathrm{m}$, $(-22.00) \mathrm{m}$ and $(-33.00) \mathrm{m}$ are measured through the Tell-Tales' readings during the loading procedure and the measured values are presented in Figure 16.

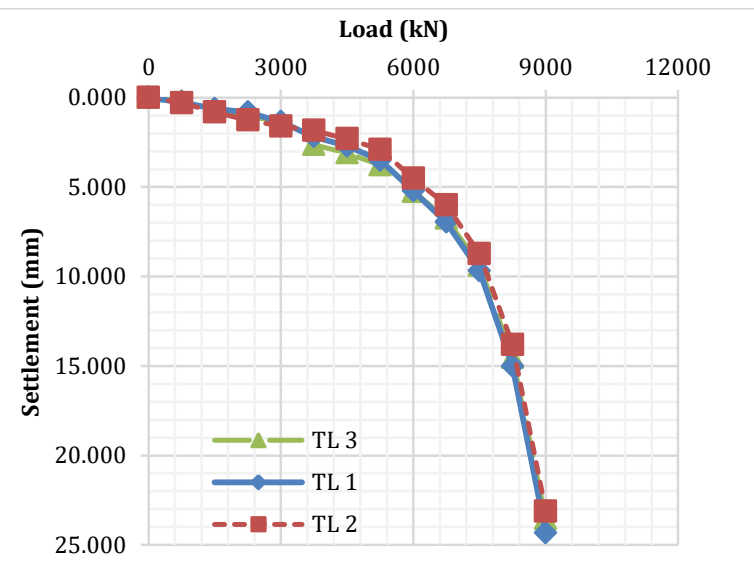

Fig.16 Tell-Tales readings of pile settlement
Figure 16 shows that measured settlement values decrease as the Tell-Tales levels increase. Moreover, Tell-Tales recorded values were lower than pile-head settlement recorded by the dial gauges that were installed at the pile head level. The difference between dial gauges and Tell-Tales' readings is due to the load transferred by friction to the surrounded soil layers at different levels of pile shaft.

\subsection{Pile load distribution}

Figure 17 demonstrates strain measurements of the twelve gauges under each loading and unloading increment. Using these measured strain values, the pile axial load can be calculated along shaft length at the gauges levels of $-1,00 \mathrm{~m},-14.00 \mathrm{~m},-29.00$, and $-33.00 \mathrm{~m}$ (see Fig.11).

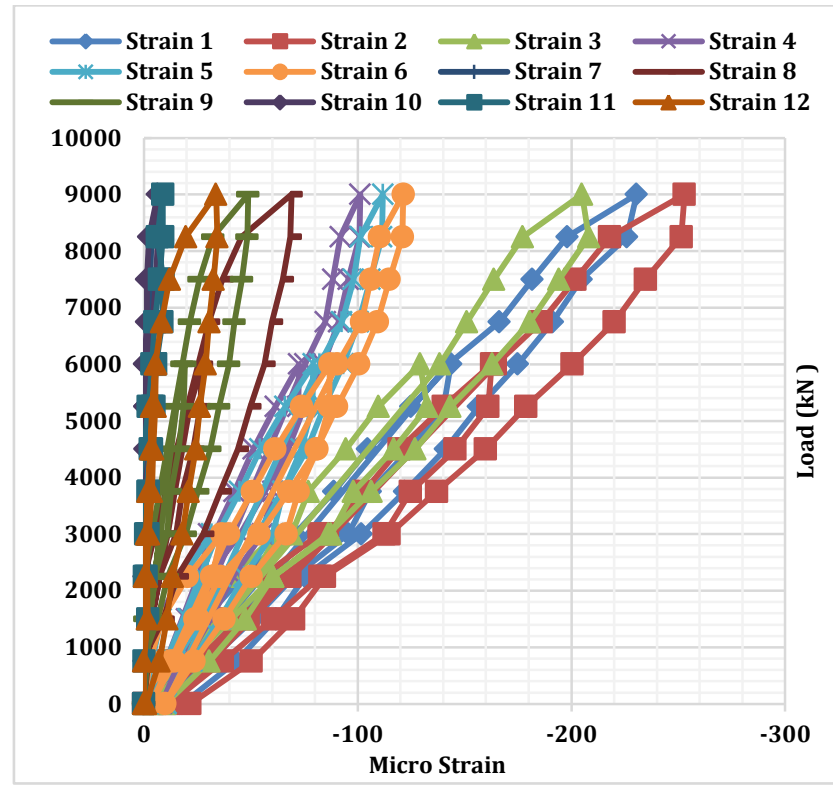

Fig 17Relation between applied load and strain gauges readings

Elastic theory (Conventional method) assumes that there is no slippage between the concrete and the steel bars at all cross-sections. The pile axial force (P) can be expressed in terms of the strain $(\varepsilon)$ as given by Equation 8.

$P=\varepsilon\left(E_{s} A s+E_{c} A c\right)$

Where,

$\varepsilon$ : Steel bars strains

$\mathrm{E}_{\mathrm{s}}$ : Steel Young's modulus $\left(\mathrm{kN} / \mathrm{m}^{2}\right)$

$\mathrm{E}_{\mathrm{c}}$ : Concrete modulus of elasticity $\left(\mathrm{kN} / \mathrm{m}^{2}\right)$

As: Steel reinforcement cross sectional area $\left(\mathrm{m}^{2}\right)$

Ac: Pile cross sectional area $\left(\mathrm{m}^{2}\right)$.

The elastic modulus of steel is $\left(21^{*} 10^{7} \mathrm{kN} / \mathrm{m}^{2}\right)$, and the concrete modulus of elasticity is estimated using the following equation (ECP 201 (2001)). Thus, pile load 
distribution along shaft at each loading increment was calculated and presented in Figure 18.

$\mathrm{E}_{\mathrm{c}}=14000 \sqrt{\mathrm{Fcu}}$

Where,

Fcu: Compressive strength of concrete material $\left(\mathrm{kg} / \mathrm{cm}^{2}\right)$.

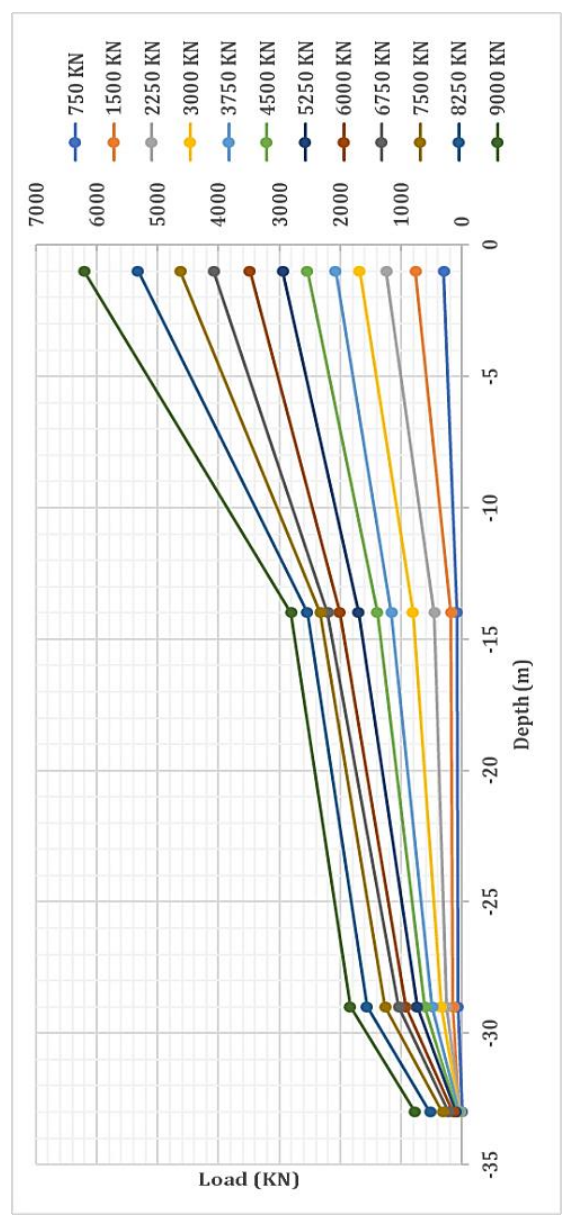

Fig 18 Calculated pile load distribution using elastic conventional method

Figure 18 indicates that the rate of load transfer to the soil in the first $1 \mathrm{~m}$ is about 8 times that for the following $13 \mathrm{~m}$. This might be attribute to the conventional method used to interpret the results that assumes that the loads are linearly proportional to the measured strain with constant elastic moduli. Fellenius (2001) noted that although the modulus of elasticity for steel is constant, the modulus of elasticity of concrete can vary within a wide range and is function of the imposed load.

As noted by Fellenius, over the large stress range imposed during a static loading test, the difference between the initial and the final moduli for the pile material can be substantial.

According to Jack Hayes, conventional methods used to estimate the modulus of elasticity of concrete can lead to errors up to $40 \%$ in loads computed from strain data. In addition, Jack Hayes and many researches recommended to use the tangent modulus analytical technique described by Fellenius for assessing pile axial load from strain values.

Fellenius stated that, the tangent modulus should be calculated using strain readings of the upper gauges that located near the pile head (at level $-1.0 \mathrm{~m}$ ) because they are unaffected by shaft resistance. Using equation 10 , the tangent modulus of the composite material is separately calculated using each of the upper three strain gauges' readings at depth of $1.00 \mathrm{~m}$ below ground surface (strain gauge No. 1, 2, and 3). The tangential modulus $\left(\mathrm{M}_{\mathrm{t}}\right)$ was determined using each strain gauge measurements by dividing the change of stress from one load increment to the next $\left(\sigma_{n+1}-\sigma_{1}\right)$ by the change of strain from one load increment to the next $\left(\varepsilon_{n+1^{-}} \varepsilon_{1}\right)$ (see Figure 17). Thus, the relation between measured strain and calculated tangent modulus can be plotted according to the three mentioned strain gauges readings, as presented in Figure 19. Equation (10) of tangential modulus can be integrated to $\sigma=\left(\frac{\mathrm{A}}{2}\right) \varepsilon^{2}+\mathrm{B} \varepsilon$ (the integration constant is zero to satisfy zero stress is calculated for zero strain). Since $\sigma=E_{s} \varepsilon$, the secant modulus $\left(E_{s}\right)$ can be represented by Equation 11.

As indicated in Fig.19, the values converge to a straight line represented by the "Best Fit Line". this line inclination formula is used to establish the expression for the secant elastic modulus as given in Equation 11. The slope of the tangent-modulus line represents coefficient (A) and its $\mathrm{y}$-intercept represents the coefficient (B).

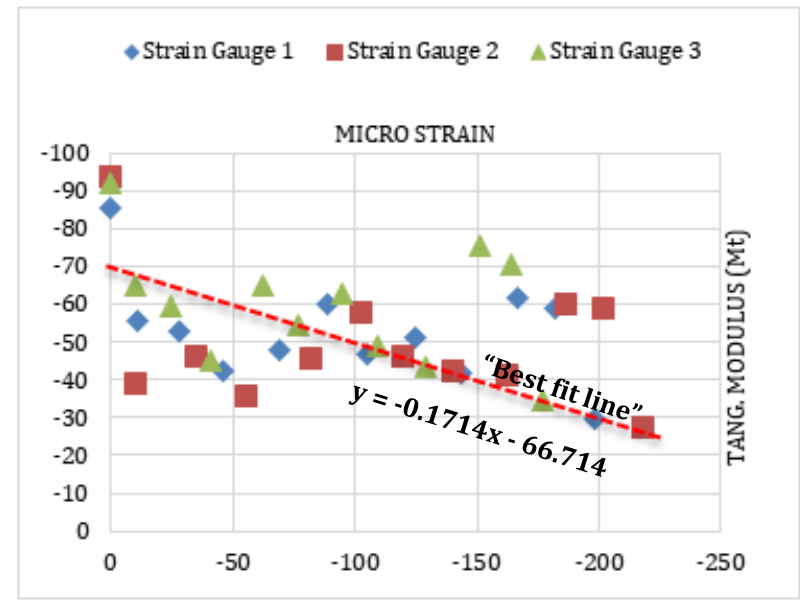

Fig.19 Relation between micro Strain and calculated tangent modulus

$M_{t}=\left(\frac{d \sigma}{d \varepsilon}\right)=A \varepsilon+B$

$\mathrm{E}_{\mathrm{s}}=0.5 \mathrm{~A} \varepsilon+\mathrm{B}$

$\sigma=\mathrm{E}_{\mathrm{s}} \varepsilon$

Where,

$\mathrm{M}_{\mathrm{t}}$ : Tangent modulus of composite pile material 
$\mathrm{E}_{\mathrm{s}}$ : Secant modulus of composite pile material

$\sigma:$ Vertical stress $\left(\mathrm{kN} / \mathrm{m}^{2}\right)$

$\varepsilon$ : measured strain $(\mu \varepsilon)$

$\mathrm{d} \sigma:\left(\sigma_{\mathrm{n}+1}-\sigma_{1}\right)$, change of stress from one load increment to the next $\left(\mathrm{kN} / \mathrm{m}^{2}\right)$

$\mathrm{d} \varepsilon:\left(\varepsilon_{\mathrm{n}+1}-\varepsilon_{1}\right)$, change of strain from one load increment to the next $(\mu \varepsilon)$.

A: slope of the tangent modulus line

B: y-intercept of the tangent modulus line.

Every measured strain value can therefore be converted to stress and load via its corresponding strain dependent secant modulus using Equation 12. Consequently, pile load distribution along shaft is calculated and plotted in Figure 20.

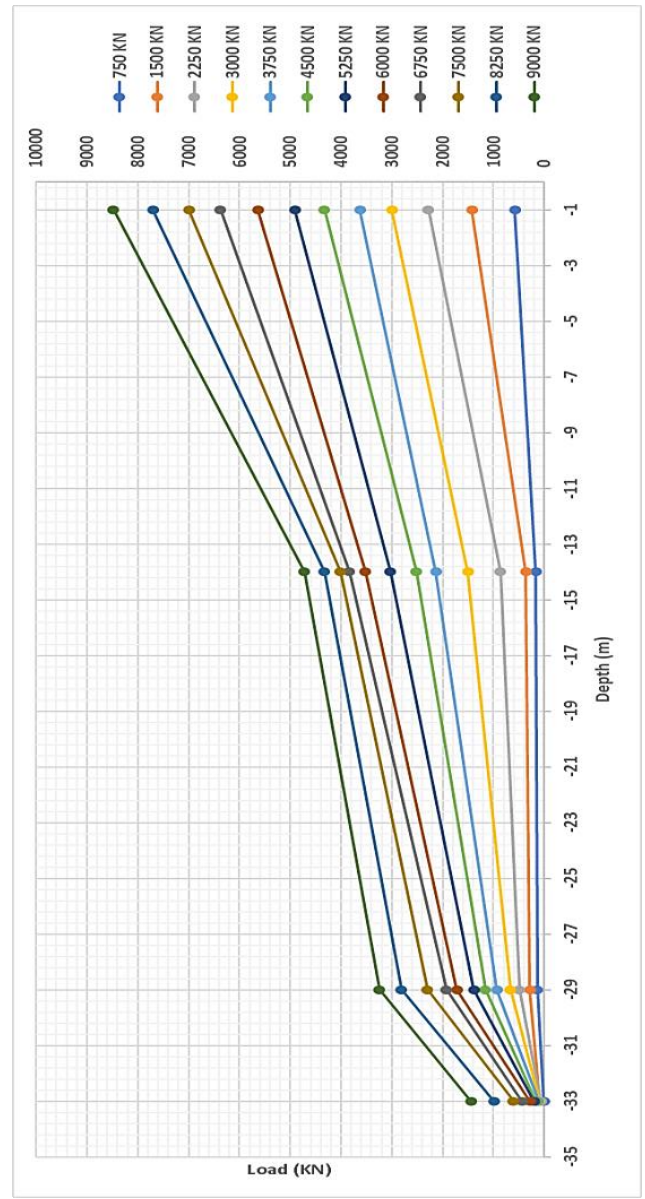

Fig.20 Calculated pile load distribution using Fellenius (2001) method

Significant difference of about $27 \%$ to $40 \%$ is apparent from Figures 18 and 20 between the obtained pile load distribution values using conventional and Fellenius methods. The calculated pile axial load using conventional method is lower than the calculated one using tangent modulus analytical technique.

According to the calculated pile distribution presented in Figure 20, about $46 \%$ of the applied load was transferred by friction to the surrounding sand layers at levels from $0.0 \mathrm{~m}$ to $-14.00 \mathrm{~m}$, and about $16 \%$ of the applied load was transferred by friction to the soft to medium clay layer at levels from $-14.00 \mathrm{~m}$ to $29.00 \mathrm{~m}$. About $21 \%$ of the applied load was transferred by friction to lower sand layer at levels from $-29.00 \mathrm{~m}$ to $-34.00 \mathrm{~m}$. Also, about $17 \%$ of total applied load was carried by bearing.

\subsection{Pile side and base resistances}

Pile bearing load was calculated at each loading increment using strain measurement of gauges at level near the pile base (see Fig. 20). The calculated bearing load was deducted from total applied load in order to determine pile total friction load at each loading increment. Relation between pile settlement, pile side and base resistances under every loading increments was obtained and plotted in Figure 21.

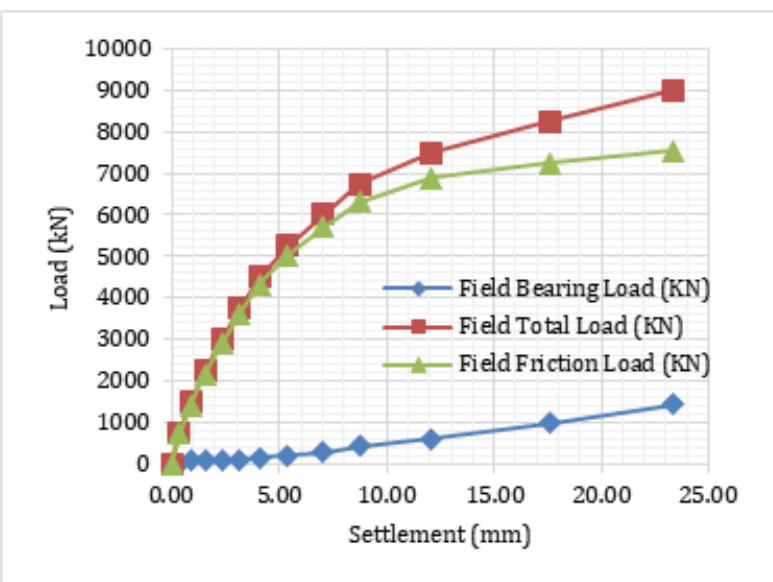

Fig.21 Relation between bearing and friction pile load with measured settlement at every loading increment

As can be seen from Figure 21, at the initial loading increments, were the settlement was less than $5 \mathrm{~mm}$, most of the applied load is transferred to soil by friction and very low value (about 1\%) of load is transferred by bearing. When pile settlement increased to be about $12 \mathrm{~mm}$ under load of $7500 \mathrm{kN}$, about $8 \%$ of applied load is transferred by bearing, and $92 \%$ by friction.

Finally, under the last applied load (9000 kN). The pile carried about $7553 \mathrm{kN}$ (83\% of total applied load) by friction resistance and about $1448 \mathrm{kN}$ (17\% of total applied load) by bearing resistance. The observed increase in pile bearing and friction resistances with pile loading could be interpreted as pile didn't achieve its ultimate capacity and still can carry loads larger than $9000 \mathrm{kN}$.

\section{Calculation of Pile Design Load using In-situ Loading Test Results}

According to Egyptian code of deep foundation (ECP202/4), if field loading test results didn't show apparent failure value, the ultimate load can be estimated as the average values that are obtained from modified Chin (1970) and Hansen (1963) methods. 
Based upon, the two mentioned methods were used to calculate pile ultimate capacity using field test measurements (Figures 22 and 23, respectively).

The pile ultimate load is calculated as $10904 \mathrm{kN}$ and $9215 \mathrm{kN}$ using modified Chin method and Hansen method, respectively. Consequently, the pile ultimate load will be the average of these two results (10060 $\mathrm{kN}$ ). By considering a safety factor of 2.0, the pile allowable load will be about (5000) kN.

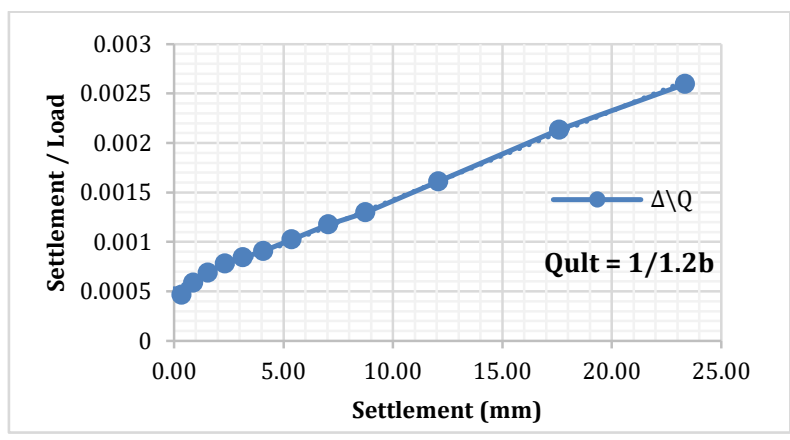

Fig 22 Relation between pile settlement and settlement/applied load ratio. According to modified Chin (1970) method

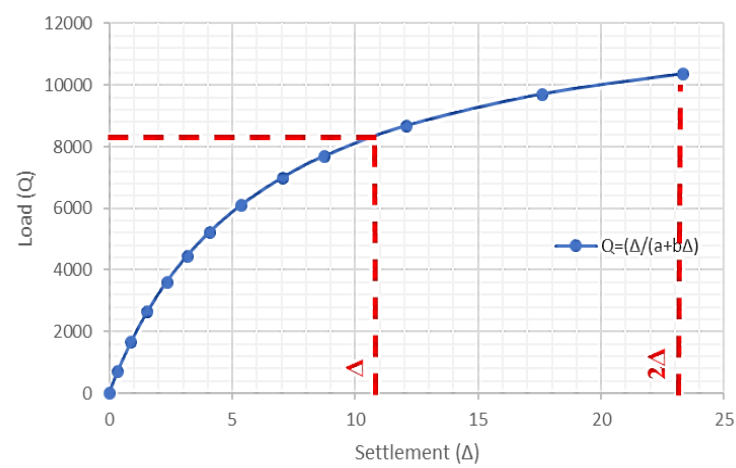

Fig 23 Relation between pile settlement and applied load according to Hansen (1963) method

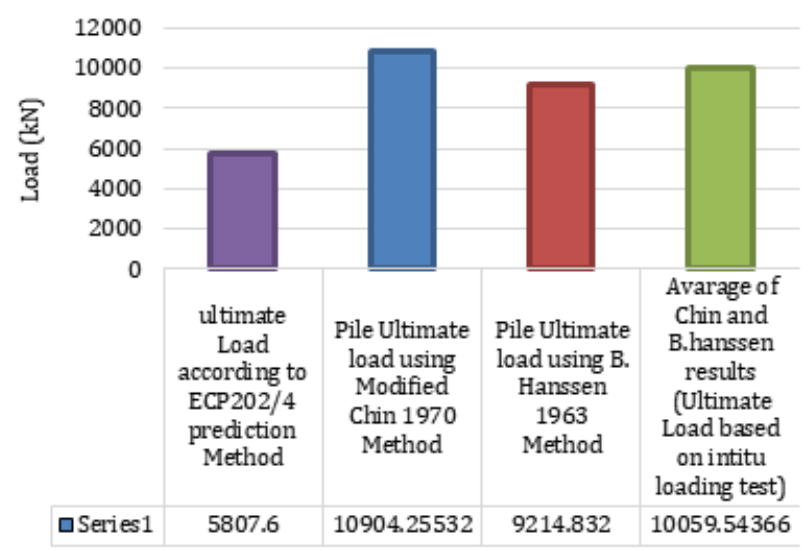

Fig.24 Large diameter bored pile ultimate capacity estimated from different methods

Figure 24 pinpoints a difference of about $18 \%$ between the calculated ultimate load using modified Chin and Hansen's methods. The two methods assumptions may be responsible of this difference. Also, the Figure highlights that the predicted pile ultimate capacity using ECP (202/4) criteria (5807.6 kN) is about $60 \%$ of the ultimate load obtained from the loading test results $(10060 \mathrm{kN})$.

\section{Comparative Analyses of Large Diameter Bored Piles using International Codes}

Pile ultimate capacity is recalculated using German standard (DIN 4014) and AASHTO LRFD Bridges criterions for large diameter bored pile utilizing the same soil parameters determined from soil laboratory and field tests (Table 5).

Figure 25 presents a comparison between the calculated pile ultimate capacity using in-situ test results with that obtained using different international codes criterions.

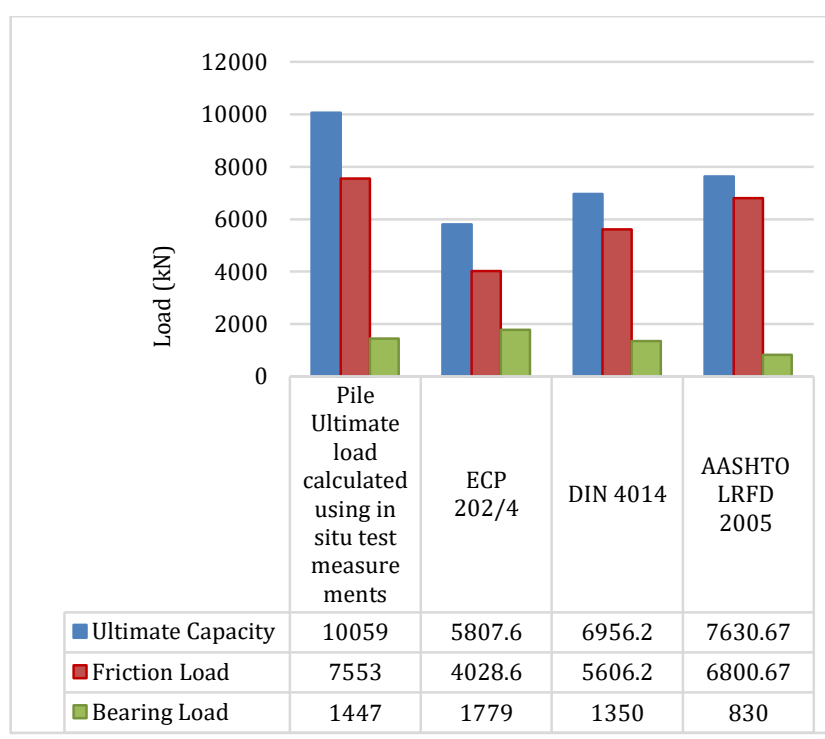

Fig.25 Comparison between pile ultimate capacity calculated using Egyptian Code, DIN 4014, AASHTO and ultimate load obtained from the loading test results

The calculated ultimate pile capacity using the Egyptian Code is apparently more conservative compared to DIN 4014 and AASHTO LRFD 2005 codes results. The pile capacity obtained using ECP202 criteria is about $76 \%$ and $83 \%$ of that obtained from the AASHTO LRFD2005 and DIN 4014 respectively.

Although, the ultimate load obtained using AASHTO method is higher than those obtained using other codes criterions, it is about $75 \%$ of the ultimate load obtained from pile loading test. It is clear that the proposed methods using different codes criterions underestimate the large diameter bored pile ultimate capacity.

\section{Conclusions}

Form the study performed, the following conclusions are drawn: 
- Well instrumented loading test is essential to obtain the ultimate capacity of large diameter bored piles.

- $\quad$ Predicting the apparent failure in an in-situ loading tests of large diameter bored piles is very difficult due to the large loads that these piles can carry.

- In static pile loading test, the difference between the initial and the final modulus of elasticity for the pile concrete material is substantial. The tangent modulus analytical technique described by Fellenius (2001) is believed to provide a good solution for assessing pile load distribution from strain data, as it takes into consideration the effect of concrete material nonlinearity. Using the conventional method to predict the load distribution can lead to load difference up to $40 \%$ of loads computed using tangent modulus.

- According to in-situ loading test results, the tested pile can safely sustain higher loads than the design load $(3000 \mathrm{kN})$. The settlement that occurred under load of $200 \%$ of the working load was less than the allowable settlement according to the ECP.

- In-situ loading test results revealed that the pile carried about $83 \%$ of total applied load by friction resistance and about $17 \%$ of total applied load by bearing resistance at the maximum applied load which was close to failure load.

- For the tested large diameter pile, side resistance started to mobilize from the start of test, however the bearing resistance started to mobilize only after pile-head settlement of about $0.5 \%$ of pile diameter occurred.

- The calculated ultimate load using modified Chin (1970) is higher than ultimate load that is calculated using Hansen (1963) with a difference about $18 \%$. The predicted pile ultimate capacity using Egyptian code of practice (ECP 202/4) criteria was about $60 \%$ of the ultimate load obtained from the loading test results.

- The calculated ultimate pile capacity using the Egyptian code (ECP202/4) is mostly more conservative compared to DIN 4014 and AASHTO LRFD 2005 codes results.

- ECP202/4, DIN4014 and AASHTO LRFD2005 proposed methods underestimate the large diameter bored pile ultimate capacity.

\section{References}

ECP 202/4. 2005. Egyptian code for soil mechanics - design and construction of foundations. Part 4, Deep foundations. The Housing and Building Research Center (HBRC), Cairo, Egypt.
DIN 4014. 1990. German association for earthworks and foundation engineering, Deutsches Institute fur Normung, Berlin, Germany.

AASHTO LRFD. 2005. bridge designs specifications - SI units, 3rd ed; Washington, DC, AASHTO.

ECP 202/2. 2005. Egyptian code for soil mechanics - design and construction of foundations. Part 2, Laboratory tests. The Housing and Building Research Center (HBRC), Cairo, Egypt.

Hazen A., 1892, Some Physical Properties of Sands and Gravels, with Special Reference to their Use in Filtration, 24th Annual Report, Massachusetts State Board of Health, Pub. Doc. No. 34, pp. 539-556.

ECP 202/1. 2005. Egyptian code for soil mechanics - design and construction of foundations. Part 1, Site investigation. The Housing and Building Research Center (HBRC), Cairo, Egypt.

ECP 202/3. 2005. Egyptian code for soil mechanics - design and construction of foundations. Part 3, Shallow Foundation. The Housing and Building Research Center (HBRC), Cairo, Egypt.

ASTM, Designation: D3441. 2004, Standard Test Method for Cone Penetration Test.

Robertson, P.K. 1990. Soil classification using the cone penetration test. Canadian Geotechnical Journal, 27(1): 151-158. doi:10. 1139/t90-014.

Robertson, P.K., and Campanella, R.G., 1983a. Interpretation of cone penetration tests - Part I (sand). Canadian Geotechnical Journal, 20(4):718-733

P.K. Robertson and K.L. Cabal, (2010). Estimating soil unit weight from CPT. 2nd International Symposium on Cone Penetration Testing, Huntington Beach, CA, USA,

Joseph E. Bowles (1997), Foundation Analysis and Design book- Exploration, sampling, and in situ soil measurements chapter, P: 180.

Bellotti, R., Ghionna, V.N., Jamiolkowski, M., and Robertson, P.K. 1989. Design parameters of cohesionless soils from in situ tests. Transportation Research Record, 1235: 45-54.

Duncan, J.M. and Buchignani, A., (1987). An Engineering Manual for Settlement Studies, Berkeley: University of California.

Geokon Inc. 1995, revised 2003. Instruction Manual, Model A-9 Retrievable Extensometer, strain gauges A 4011 PP.2435.

ECP 201 (2001). Egyptian code for design and construction of reinforced concrete structures.

Fellenius, B. H., 2001. From strain measurements to load in an instrumented pile. Geotechnical News Magazine, Vol. 19, No. 1, pp 35 - 38.

Hayes J., interpreting strain measurements from load tests in bored piles load test Inc., Gainesville, Florida, USA.

Chin, F. K., (1970). Estimation of the ultimate load of piles from tests not carried to failure. Proc., 2nd. South-East Asian Conf. on Soil Eng., Singapore, pp.81-90.

Hansen, J. B., (1963). Discussion on hyperbolic stress-strain response in cohesive soils. ASCE, Vol. 89, SM4, pp. 241-242. 